\title{
Electro-optic properties of exciplex-type organic electroluminescence devices depending on the technologies of active-layer preparation
}

\author{
${ }^{1}$ Ivaniuk K., ${ }^{1}$ Chapran M., ${ }^{1}$ Cherpak V., ${ }^{1}$ Barylo G., ${ }^{1}$ Stakhira P., \\ ${ }^{1,2}$ Hotra Z., ${ }^{3}$ Hladun M. and ${ }^{4}$ Dudok T. \\ ${ }^{1}$ Lviv Polytechnic National University, 12 S. Bandera Street, 79013 Lviv, Ukraine, \\ stakhira@polynet.lviv.ua \\ ${ }^{2}$ Rzeszów University of Technology, W. Pola 2, 35-959 Rzeszów, Poland \\ ${ }^{3}$ Lviv Branch of European University, 7 Kushevych Street, 79000 Lviv, Ukraine \\ ${ }^{4}$ Vlokh Institute of Physical Optics, 23 Dragomanov Street, 79005 Lviv, Ukraine
}

Received: 24.04 .2015

\begin{abstract}
We have studied electroluminescence and impedance properties of exciplex-type organic light-emitting devices (OLEDs) based on 4,4,4"-tris[3methylphenyl(phenyl)-aminotriphenylamine (m-MTDATA) and 4,7-diphenyl-1,10phenanthroline (Bphen), which depend on the technologies applied to form active layers of the devices. A comparative analysis of the current-voltage characteristics and impedance spectroscopy of the layered and composite devices have revealed the influence of device technology on the injection of charge carriers in the active layers of OLED structures. We have found a correlation between the negative capacitance observed at low frequencies in the exciplex-type layered OLEDs and the emitting recombination processes.
\end{abstract}

Keywords: organic light-emitting devices, exciplex, impedance spectroscopy, negative capacitance

PACS: $72.40 .+\mathrm{W}$

UDC: 621.38

\section{Introduction}

Recent advances in the technologies of organic light-emitting diodes (OLEDs) have provided conditions for their competitive use as basic components for production of advanced information displays and lighting systems $[1,2]$. As a result, portable displays for smartphones and curved TVs based on OLEDs have become available commercially [3].

It has often been remarked that the electroluminescence (EL) emission spectra of OLEDs differ or, at least, are more complex than the photoluminescence spectra of their light-emitting layers $[4,5]$. On the one hand, this can result from a chemical nature of the functional organic compounds, i.e. their ability to form bimolecular excited states in a solid state [5]. On the other hand, the reason can be related to the device technology [6]. A cross-interaction of electrons from the LUMO level of a donor molecular material and holes from the HOMO level of an acceptor molecular material occurs, leading to formation of an exciplex on a contacting molecular interface $[4,5]$. Recently it has been widely used for developing white OLEDs by mixing a molecular exciton emission (usually a blue one) and an exciplex emission (usually orange) [7, 8]. A necessary condition for the formation of exciplexes is availability of high-energy barriers for the charge carriers in the organic-organic interface [7]. Another determining factor is spatial topology of the organic-organic interface, which is imposed by the technology of functional layers [9]. 


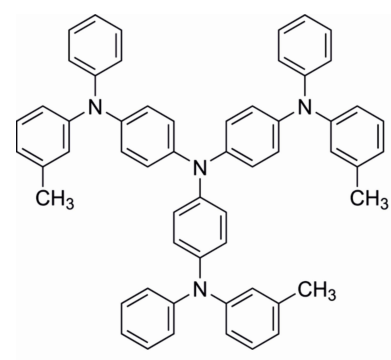

m-MTDATA

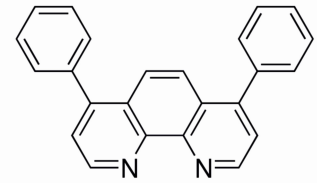

Bphen
Fig. 1. Chemical formulae of m-MTDATA and Bphen.

Notice that the technology is more developed for the case of the composite structures and still underdeveloped for the planar film structures [4-9]. A progress in the field of high-efficiency exciplex-type OLEDs can be reached by searching for suitable donor and acceptor materials and novel technological solutions to form the devices [1].

In this article, we report on detailed electro-optic studies, using the impedance spectroscopy, of the exciplex-type OLEDs based on 4,4,4"-tris[3-methylphenyl(phenyl)-aminotriphenylamine (m-MTDATA) [10, 11] and 4,7-diphenyl-1,10-phenanthroline (Bphen) [10]. The relevant chemical formulae are displayed in Fig. 1. Our main point is dependence of the corresponding properties on the technologies of preparation of the active layers, which represent planar or bulk heterostructures. We have chosen these materials issuing from the following considerations: both m-MTDATA and Bphen are capable of forming exciplexes (see Ref. [11]), with availability of thermally activated delayed fluorescence, provided that both the singlet and triplet excitons take part in generating the light emission [11].

\section{Experimental methods}

Two types of EL devices, A and B, were fabricated by means of vacuum deposition of organic semiconductor layers and metal electrodes onto pre-cleaned ITO-coated glass substrates under the vacuum of $10^{-5}$ Torr. The devices were made using step-by-step deposition or codeposition of different organic layers. $\mathrm{CuI}$ was used for preparing a hole-transporting layer [12]. m-MTDATA and Bphen were applied for the fabrication of donor and acceptor layers, respectively [11]. Since $\mathrm{Ca}$ is highly reactive and corrodes quickly in the ambient atmosphere, a Ca layer topped with a $200 \mathrm{~nm}$ aluminium layer was used as a cathode. The $\mathrm{A}$ and $\mathrm{B}$ structures are as follows:

(A) ITO $/ \mathrm{CuI}(8 \mathrm{~nm}) / \mathrm{m}-\mathrm{MTDATA}(30 \mathrm{~nm}) / \operatorname{Bphen}(30 \mathrm{~nm}) / \mathrm{Ca}(50 \mathrm{~nm})) / \mathrm{Al}(200 \mathrm{~nm})$;

(B) ITO $/ \mathrm{CuI}(8 \mathrm{~nm}) / \mathrm{m}-\mathrm{MTDATA}: B p h e n(80 \mathrm{~nm}) / \mathrm{Ca}(50 \mathrm{~nm})) / \mathrm{Al}(200 \mathrm{~nm})$.

The active area of the devices thus obtained was $3 \times 6 \mathrm{~mm}^{2}$. The density-voltage and luminance-voltage characteristics were measured using a semiconductor parameter analyzer HP 4145A in air, with no immediate passivation after formation of the devices. The brightness measurements were done using a calibrated photodiode $[13,14]$. The EL spectra were recorded with an Ocean Optics USB2000 spectrometer.

Impedance spectroscopy was used for investigating bulk and interface parameters of the devices. The impedance was measured in the frequency range of $10 \div 10^{6} \mathrm{~Hz}$ at constant bias voltages of 0, 1.0, 2.0 and 3.0 V, using an instrument 'AUTOLAB' (Eco Chemie, the Netherlands) equipped with FRA-2 and GPES software. The frequency dependences of the complex resistivity $Z$ were analyzed with a graphic-analytical method, using ZView 2.3 software (Scribner Associates). The approximation inaccuracy did not exceed 6\%.

\section{Results and discussion}

As shown in Fig. 2, the EL spectra of the devices A and B are very similar to those reported previously [11]. Hence, the majority of the emission bands originate from the exciplex $(567 \mathrm{~nm})$. Different widths of the EL spectra measured for the devices A and B can be explained as follows. 


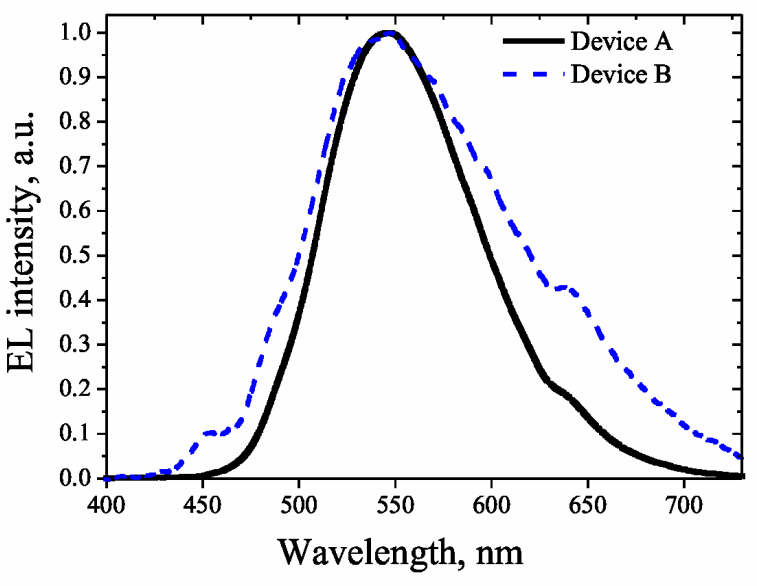

Fig. 2. Normalized EL spectra of our devices.

In case of the EL spectrum for the device $\mathrm{A}$, we deal with a planar heterojunction with an interface restricted due to the interaction. This is in contrast with the EL spectra of the molecular mixture where the extra interface between MTDATA and Bphen molecules is more developed, thus leading to expansion of a longwavelength region and to appearance of a shoulder in the vicinity of $640 \mathrm{~nm}$ [14]. In addition, the EL spectrum of the device $B$ reveals a band characteristic for the fluorescent MTDATA emission. It arises from recombination of the excitons formed by direct charge injection from the electrodes into MTDATA (see Fig. 3). Unlike the device B, only the exciplex recombination exists in case of the device A.
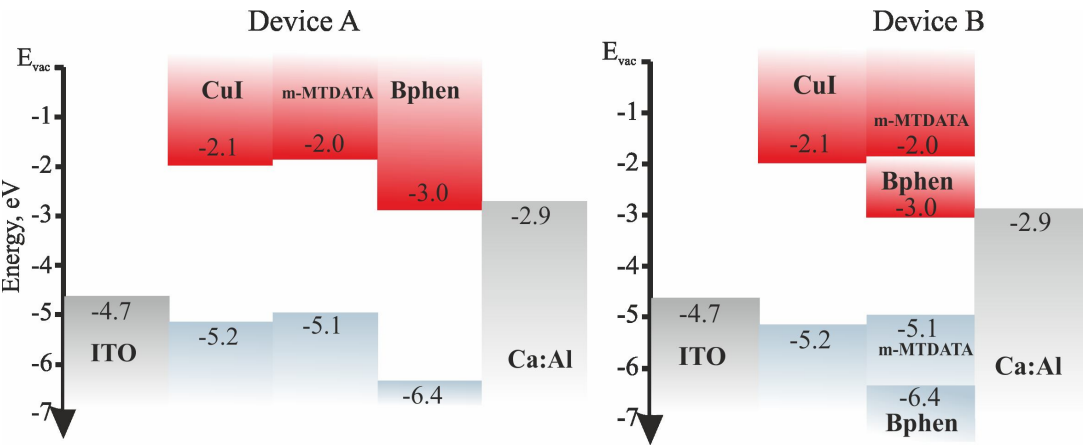

Fig. 3. Energy-band diagram of the devices $A$ and $B$ (see Refs. [11, 12] for better explanation).

Fig. 4 shows the current density-voltage and luminance-voltage characteristics of our devices. The switch-on voltage for the devices $\mathrm{A}$ and $\mathrm{B}$ are 2.6 and $4.9 \mathrm{~V}$, respectively (see Fig. 4a). As seen from Fig. 3, a low switch-on voltage for the device A can be attributed to low potential barriers for the both types of charge carriers in the organic/electrode interface (see also Ref. [15]). The OLEDs parameters are summarized in Table 1.
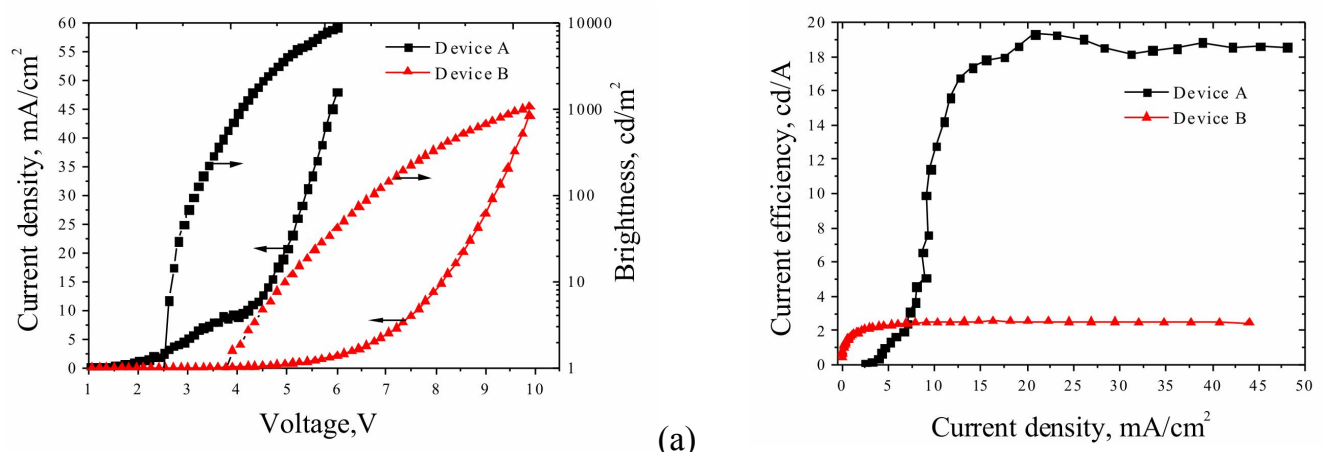

(a)

(b)

Fig. 4. Current density-voltage and luminance-voltage characteristics of our devices (a), and their current efficiency-current density characteristics (b).

Ukr. J. Phys. Opt. 2015, Volume 16, Issue 2 
Table 1. Summary of EL characteristics of our devices.

\begin{tabular}{|c|c|c|c|c|c|c|c|c|}
\hline \multirow[t]{2}{*}{ Device } & \multirow[b]{2}{*}{$\begin{array}{l}\sum \\
0 \\
0\end{array}$} & \multirow{2}{*}{ 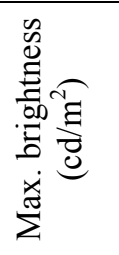 } & \multirow{2}{*}{ 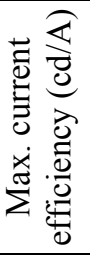 } & \multirow{2}{*}{ 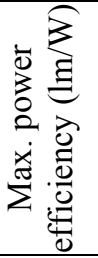 } & \multirow{2}{*}{ 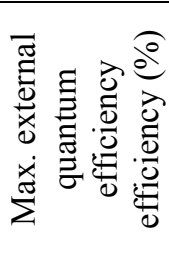 } & \multicolumn{3}{|c|}{$1000 \mathrm{Cd} / \mathrm{m}^{2}$} \\
\hline & & & & & & 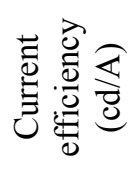 & 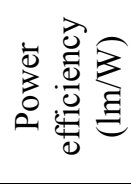 & 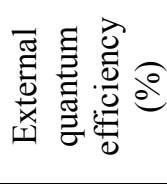 \\
\hline $\begin{array}{c}\text { Device } \\
\text { A }\end{array}$ & 2.65 & $\begin{array}{c}8900 \text { at } \\
6 \mathrm{~V}\end{array}$ & 19.32 & 12.13 & 5.28 & 11.44 & 8.76 & 3.14 \\
\hline $\begin{array}{c}\text { Device } \\
\text { B }\end{array}$ & 4.92 & $\begin{array}{c}1070 \text { at } \\
10 \mathrm{~V}\end{array}$ & 2.55 & 1.07 & 0.86 & 2.45 & 0.79 & 0.82 \\
\hline
\end{tabular}

As seen from Fig. 5, the Commission Internationale de l'Eclairage (CIE) chromaticity coordinates $(x ; y)$ found for the devices $\mathrm{A}$ and $\mathrm{B}$ are respectively $(0.39 ; 0.51)$ (the corresponding colour temperature equals to $4100 \mathrm{~K})$ and $(0.39 ; 0.47)$ (the colour temperature of $3800 \mathrm{~K}$ ).

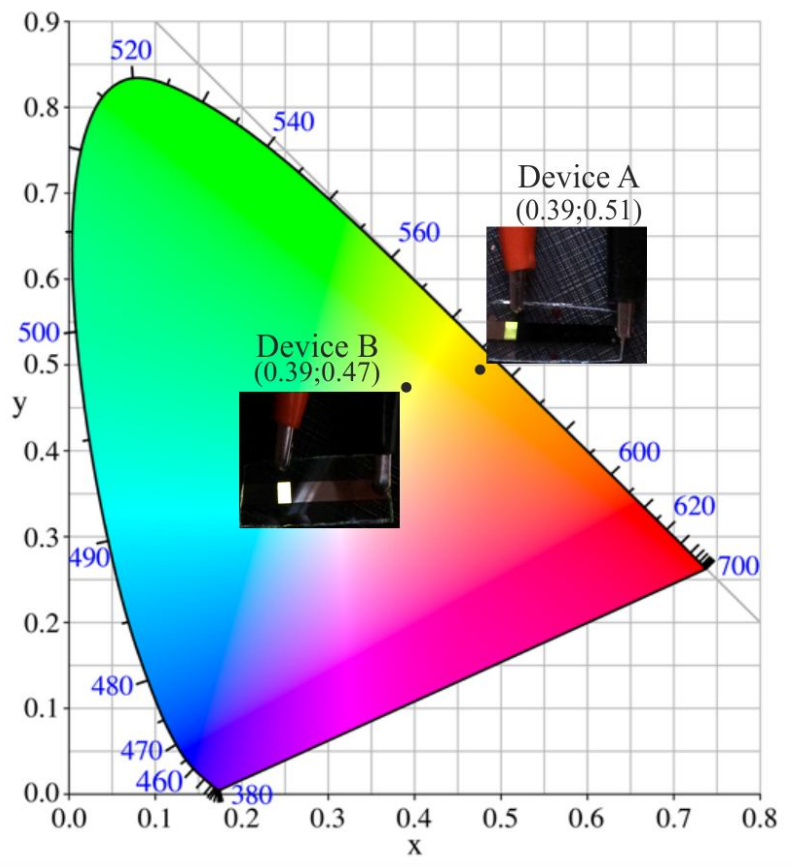

Fig. 5. A CIE1931 chromaticity diagram and photographs of our devices taken at $5 \mathrm{~V}$ (the device $\mathrm{A}$ ) and $9 \mathrm{~V}$ (the device $B$ ).

Important additional information on the generation and recombination processes taking part in our OLEDs can be obtained from the impedance spectroscopy data $[12,16]$. To investigate the bulk and interface parameters, we have employed the impedance spectroscopy. The Nyquist plots for the layered (A) and composite (B) structures are shown respectively in Fig. $6 \mathrm{a}$ and $6 \mathrm{~b}$ for the cases of forward bias varying from 0 to $+3 \mathrm{~V}$. The relationship between the real $(Z)$ and imaginary $\left(Z^{\prime}\right)$ parts of the complex impedance (i.e., the Nyquist plot) has the shape of a semicircle. This can be modelled using an equivalent circuit consisting of an $R C$ circuit and a contact resistance $R_{S}$ connected in series (see Fig. 6c). The parameters $R_{1}$ and $C_{1}$ describe the bulk and barrier parameters for the device $\mathrm{A}$ at the forward biases ranging from 0 to $+2 \mathrm{~V}$ and for the device $\mathrm{B}$ at the forward biases ranging from 0 to $+3 \mathrm{~V}[12]$. 

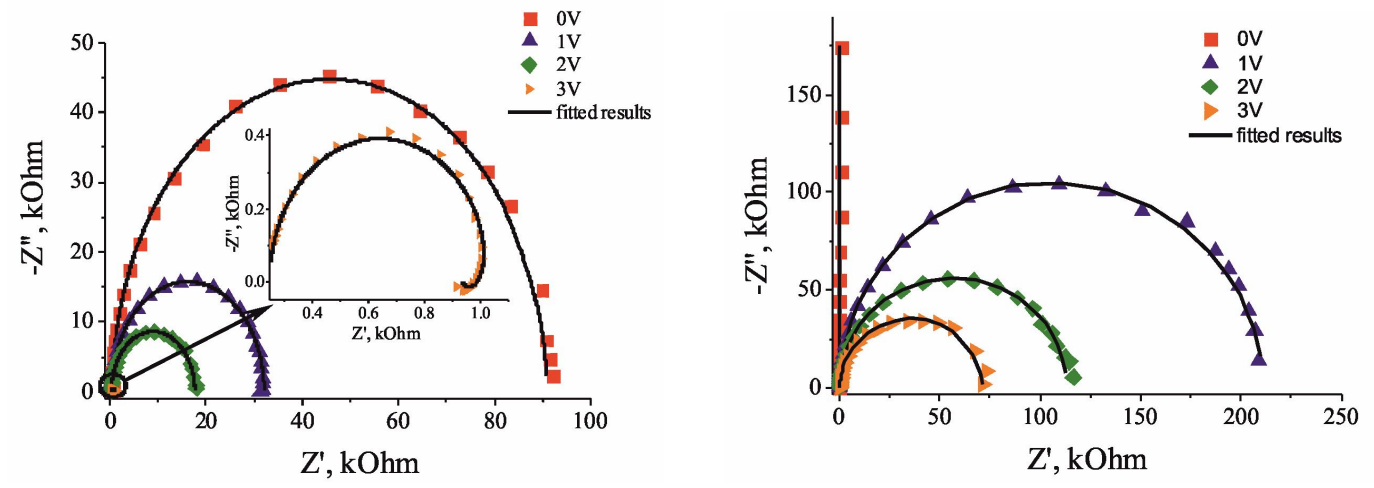

(a)

(b)
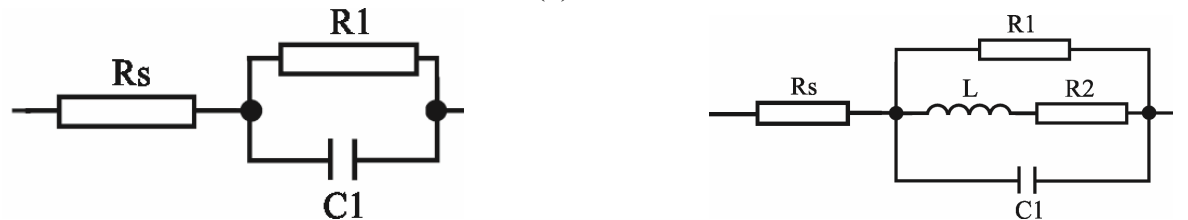

(c)

Fig. 6. Nyquist plots for the heterostructures A (a) and B (b). Panels (c) and (d) show relevant equivalent circuits of those structures.

Table 2. Parameters calculated for the equivalent circuits corresponding to Fig. $6 \mathrm{c}$ and $6 \mathrm{~d}$.

\begin{tabular}{|c|c|c|c|c|c|c|c|c|}
\hline \multirow{2}{*}{$\begin{array}{c}\text { Bias, } \\
\mathrm{V}\end{array}$} & \multicolumn{2}{|c|}{$R_{S}, \mathrm{Ohm}$} & \multicolumn{2}{c|}{$R_{1}, \mathrm{kOhm}$} & \multicolumn{2}{c|}{$C_{1}, \mathrm{nF}$} & $R_{2}, \mathrm{kOhm}$ & $L, \mathrm{H}$ \\
\cline { 2 - 8 } & $\begin{array}{c}\text { Device } \\
\mathrm{A}\end{array}$ & $\begin{array}{c}\text { Device } \\
\mathrm{B}\end{array}$ & $\begin{array}{c}\text { Device } \\
\mathrm{A}\end{array}$ & $\begin{array}{c}\text { Device } \\
\mathrm{B}\end{array}$ & $\begin{array}{c}\text { Device } \\
\mathrm{A}\end{array}$ & $\begin{array}{c}\text { Device } \\
\mathrm{B}\end{array}$ & $\begin{array}{c}\text { Device } \\
\mathrm{A}\end{array}$ & $\begin{array}{c}\text { Device } \\
\mathrm{A}\end{array}$ \\
\hline 0 & 299.6 & 351.1 & 90 & 275 & 3.49 & 1.8 & - & - \\
\hline 1 & 284.9 & 326.7 & 32 & 211 & 3.46 & 1.80 & - & - \\
\hline 2 & 272.8 & 322.1 & 17 & 112 & 3.45 & 1.83 & - & - \\
\hline 3 & 247.5 & 357.6 & 0.8 & 70 & 2.84 & 1.81 & 5.5 & 0.184 \\
\hline
\end{tabular}

It should be noted that the equivalent electrical circuit depicted in Fig. $6 \mathrm{c}$ is typical for the majority of organic light-emitting heterostructures [17]. In case of the planar heterostructure subjected to increasing (up to $3 \mathrm{~V}$ ) voltage, we observe an inductive response, or a so-called 'negative capacitance' effect in the Nyquist plot for the device A (see the fourth quadrant of the complex impedance in Fig. 6a, Fig. 7 and Refs. [15, 18]). The equivalent circuit for such a structure is represented in Fig. 6d.

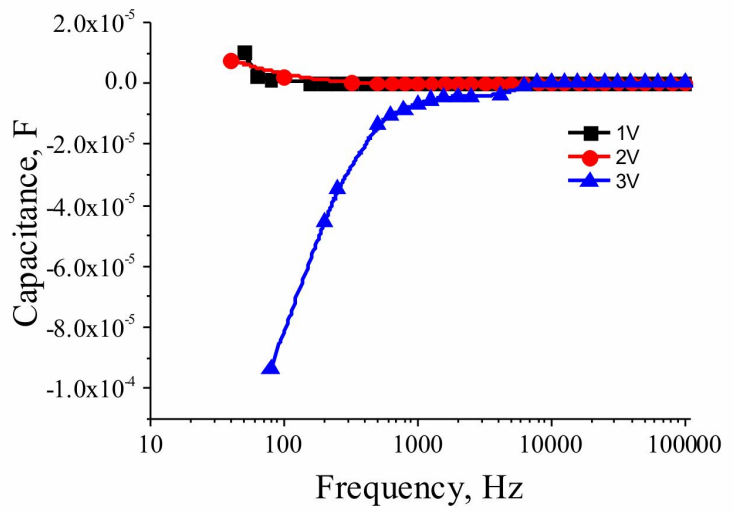

Fig. 7. Capacitance versus frequency for different bias voltages (1,2 and $3 \mathrm{~V})$, as measured for the device $A$.

Ukr. J. Phys. Opt. 2015, Volume 16, Issue 2 
The nature of the inductive component (or the 'negative capacitance') in the structures of the latter type has not yet been elucidated completely $[15,18]$. In our case the most probable explanation is as follows. Under the influence of bipolar injection from the electrodes (the absence of injection barriers for the both types of charge carriers), excited states are formed in the organic light-emitting layer. This is followed by non-emitting and emitting annihilations and the appearance of recombination drift current [15]. As shown in Fig. 4a, the EL occurs at the voltages as low as $2.6 \mathrm{~V}$. Table 2 testifies that the capacitance is roughly constant at low bias voltages, which is caused by the accumulation of charges. When the bias voltage is above the threshold, recombination of the accumulated charge takes place and, as a consequence, the capacitance decreases. Regarding the resistance, one can see its monotonous decrease when the bias voltages remain lower than the switch-on voltage for the heterostructure $\mathrm{A}$, and an abrupt drop in the resistance above the switch-on voltage. This agrees well with the current density-voltage plot shown in Fig. 4a.

Note that the inductive response is not observed in case of the composite heterojunction (see Fig. 6c). This difference can be explained by analyzing the energy band diagram. For the composite heterostructure (see the device B in Fig. 3) we have an additional energy barrier for the organic-inorganic interfaces (cca $0.9 \mathrm{eV}$ for $\mathrm{Ca}: \mathrm{Al} / \mathrm{m}-\mathrm{MTDATA}$ and cca $1.2 \mathrm{eV}$ for CuI/Bphen). This increases significantly the switch-on voltage, when compared to that typical for the planar heterostructure A.

An additional confirmation of this hypothesis is the presence of a short-wavelength band in the EL spectrum for the heterostructure B, which is characteristic for the exciton recombination. Obviously, it requires some additional energy to inject electrons (see Fig. 2). As seen from Table 2, the resistance parameters calculated for the equivalent circuit depend linearly on the bias voltage applied. This is because the switch-on voltage for the heterostructure $\mathrm{B}$ is $4.9 \mathrm{~V}$, which is much higher than the limiting maximum bias voltage for the impedance studies $(3 \mathrm{~V})$.

\section{Conclusions}

In the present work we have shown that the formation of exciplex-type OLEDs using codeposition of organic donor (m-MTDATA) or acceptor (Bphen) materials broadens the spectral EL band, when compared with the layered structure. This is due to (i) bulk interface character of the contacting molecules, which increases the probability of formation of exciplex states with different activation energies, and (ii) presence of the excitonic emission linked with m-MTDATA. Moreover, the layered structures exhibit a much lower threshold switch-on voltage. It is equal to $2.6 \mathrm{~V}$, while the bulk structures are characterized by the value $4.9 \mathrm{~V}$ ). The current efficiency and the brightness of layered structures are much higher than those peculiar for the bulk structures.

The impedance spectroscopy studies of the layered structures based upon both experiments and simulations indicate unambiguously that there are no energy barriers at the anode/donor and acceptor/cathode interfaces. On the contrary, additional interfacial organic/organic, anode/acceptor and donor/cathode energy barriers appear in case of the composite structures. We suggest that the negative capacitance of the layered structures appearing at the low frequencies and at the voltages exceeding some threshold is due to the recombination drift current resulting from the emitting recombination.

\section{References}

1. Adachi C, 2014. Third-generation organic electroluminescence materials. Jpn. J. Appl. Phys. 53: 060101 . 
2. Wang B, Helander M G, Qiu J, Puzzo D P, Greiner M T, Hudson Z M, Wang S, Liu Z W and $\mathrm{Lu} \mathrm{Z} \mathrm{H,} \mathrm{2011.} \mathrm{Unlocking} \mathrm{the} \mathrm{full} \mathrm{potential} \mathrm{of} \mathrm{organic} \mathrm{light-emitting} \mathrm{diodes} \mathrm{on} \mathrm{flexible} \mathrm{plastic.}$ Nature Photonics. 5: 753-757.

3. Tseng F M, Cheng A C and Peng Y N, 2009. Assessing market penetration combining scenario analysis, Delphi, and the technological substitution model: The case of the OLED TV market. Technol. Forecast. Soc. Change. 76: 897-909.

4. Cherpak V, Stakhira P, Minaev B, Baryshnikov G, Stromylo E, Helzhynskyy I, Chapran M, Volyniuk D, Hotra Z, Dabuliene A, Tomkeviciene A, Voznyak L and Grazulevicius J V, 2015. Mixing of phosphorescent and exciplex emission in efficient organic electroluminescent devices. ACS Appl. Mater. Interfaces. 7: 1219-1225.

5. Kalinowski J, Cocchi M, Virgili D and Sabatini C, 2006. Charge photogeneration effect on the exciplex emission from thin organic films. Appl. Phys. Lett. 89: 011105.

6. Zhang G, Li W, Chu B, Su Z, Yang D, Yan F, Chen Y, Zhang D, Han L, Wang J, Liu H, Che

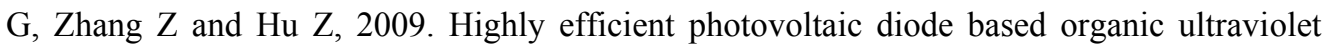
photodetector and the strong electroluminescence resulting from pure exciplex emission. Organ. Electron. 10: 352-356.

7. Michaleviciute A, Gurskyte E, Volyniuk D, Cherpak V, Sini G, Stakhira P and Grazulevicius J V, 2012. Star-shaped carbazole derivatives for bilayer white organic light-emitting diodes combining emission from both excitons and exciplexes. J. Phys. Chem. 116: 20769-20778.

8. Singh S, Mohapatra Y, Qureshi M and Manoharan S, 2005. White organic light-emitting diodes based on spectral broadening in electroluminescence due to formation of interfacial exciplexes. Appl. Phys. Lett. 86: 113505.

9. Goushi K and Adachi C, 2012. Efficient organic light-emitting diodes through up-conversion from triplet to singlet excited states of exciplexes. Appl. Phys. Lett. 101: 023306.

10. Graves D, Jankus V, Dias F and Monkman A, 2014. Photophysical investigation of the thermally activated delayed emission from films of m-MTDATA:PBD exciplex. Adv. Funct. Mater. 24: 2343-2351.

11. Zhang T, Chu B, Li W, Su Z, Peng Q, Zhao B, Luo Y, Jin F, Yan X, Gao Y, Wu H, Zhang F, Fan D and Wang J, 2014. Efficient triplet application in exciplex delayed-fluorescence oleds using a reverse intersystem crossing mechanism based on a $\delta \mathrm{e}_{\mathrm{s}-\mathrm{t}}$ of around zero. ACS Appl. Mater. Interfaces. 6: 11907-11914.

12. Stakhira P, Cherpak V, Volynyuk D, Ivastchyshyn F, Hotra Z, Tataryn V and Luka G, 2010. Characteristics of organic light emitting diodes with copper iodide as injection layer. Thin Solid Films. 518: 7016-7018.

13. Greenham N, Friend R and Bradley D, 1994. Measuring the efficiency of organic lightemitting devices. Adv. Mater. 6: 491-494.

14. Cherpak V, Stakhira P, Minaev B, Baryshnikov G, Stromylo E, Helzhynskyy I, Chapran M, Volyniuk D, Tomkuté-Lukšiené D, Malinauskas T, Getautis V, Tomkeviciene A, Simokaitiene J, and Grazulevicius JV, 2014. Efficient "Warm-White" OLEDs Based on the Phosphorescent bis-Cyclometalated iridium(III) Complex J. Phys. Chem. 118: 11271-11278.

15. Ehrenfreunda E, Lungenschmied C, Dennler G, Neugebauer H and Sariciftci N, 2007. Negative capacitance in organic semiconductor devices: Bipolar injection and charge recombination mechanism. Appl. Phys. Lett. 91: 012112.

16. Forero-Lenger S, Gmeiner J, Brutting W and Schwoerer M, 2000. Impedance spectroscopy of polymeric light emitting devices based on different poly ( $\mathrm{p}$-phenylene-vinylene) derivatives. 
Synth. Met. 111-112: 165-168.

17. Meier M, Karg S and Riess W, 1997. Light-emitting diodes based on poly-p-phenylenevinylene: II. Impedance spectroscopy. J. Appl. Phys. 82: 1961-1966.

18. Zhang X W, Xu J W, Xu H R, Wang H, Xie C L, Wei B, Jiang X Y and Zhang Z L, 2013. Elucidation of carrier injection and recombination characteristics with impedance and capacitance in organic light-emitting diodes and the frequency effects. J. Phys. D: Appl. Phys. 46: 055102.

Ivaniuk K., Chapran M., Cherpak V., Barylo G., Stakhira P., Hotra Z., Hladun M. and Dudok T. 2015. Electro-optic properties of exciplex-type organic electroluminescence devices depending on the technologies of active-layer preparation. Ukr.J.Phys.Opt. 16: 95 - 102.

Анотація: Досліджено електролюмінісцентні $i$ імпедансні властивості органічних світлодіодів ексіплексного типу на основі 4,4,4 "трис [3-метилфеніл (феніл) амінотрифениламін (м-МТDАТА) і 4,7-діфеніл- 1,10-фенантроліна (Bphen), які залежать від використаних технологій при формуванні активних шарів пристроїв. На основі порівняльного аналізу вольт-амперних характеристик $i$ імпедансної спектроскопії пошарових і композиційних пристроїв виявлено вплив технології виготовлення пристрою на інжекцію носїв заряду в активні шари світлодіодних структур. Встановлена кореляція між негативною ємністю та випромінювальними процесами рекомбінації, яка спостерігається в області низьких частот пошарових органічних світлодіодів ексіплексного типу. 